\title{
脳血管障害の超早期内視鏡所見と消化管出血
}

\author{
土井 章弘・元木 基嗣・吉野 公博・馬場 義美 \\ 武本 本久・小林 良一*·原田 仁人*・片木 良典**
}

\section{Acute Gastric Changes and Gastrointestinal Bleeding in Patients with Cerebrovascular Accidents}

\author{
Akihiro Doi, Mototsugu Motoki, Kimihiro Yoshino, Yoshimi Baba, \\ Motohisa Takemoto, Ryoighi Kobayashi*, Hitoshi Harada* \\ and YoshinORI KATAGI** \\ Department of Neurological Surgery, Kagawa Prefectural Central Hospital, Takamatsu 760 \\ *Department of Internal Medicine, Kagawa Prefectural Central Hospital \\ **Department of Neurological Surgery, Sumitomo Besshi Hospital
}

\begin{abstract}
Summary
Pathogenesis of gastrointestinal bleeding (GI bleeding) following cerebrovascular accidents (CVA) was studied by gastroendoscopy.

Gastroendoscopic examinations were performed in patients with acute cerebrovascular accidents. These patients were operated on except for 2 cases. The gastroendoscopic examination was performed under general anesthesia just before or after the operation. Forty seven patients were examined ( 35 cerebral hemorrhages, nine subarachnoid hemorrhages, two infarctions, one moyamoya). The gastroscopy was performed in 25 cases within 24 hours from the onset of the CVA.

Acute gastric changes within 24 hours were mainly gastric petechiae (GP). These findings were classified as follows: $G P(1)$, petechiae localized in the fundal region; $G P(2)$, petechiac observed diffusely and mainly in the fundal region; and GP(3), petechiae observed on the whole gastric wall with bleeding. GI bleeding and the degree of petechiae were closely related. GI bleeding was noticed in $25 \%$ of GP(1), 89\% of GP(2) and $100 \%$ of $\operatorname{GP}(3)$. No fresh ulcerative findings were noted within 24 hours in our cases. Acute gastric changes were related to the level of consciousness. CT scans showed that cerebral hemorrhage frequently involved the hypothalamic region in cases of GP (2) or GP(3).

It is concluded that characteristic acute gastroendoscopic findings within 24 hours from the onest of CVA are petechiae and the main cause of GI bleeding are these petechiae. Mucosal ulceration of the stomache and duodenum are secondary changes following petechiae.
\end{abstract}

Key words: cerebrovascular accidents, gastric mucosa, gastrointestinal bleeding, petechiae

香川県立中央病院腈神経外科

*香川県立中央病院内科

**住友別子病院脳神経外科

〔連絡先： $\mathbf{7} 760$ 高松市番町 5 丁目4-16, 香川県立中央病院脳神経外科，土井章弘]

1980 年10月24日 受稿 


\section{Iはじめに}

高血圧性脳出血，クモ膜下出血などの腷血管障害に消 化管出血をきたすことは，脳神経外科医においてもしば しば経験するところである。この消化管出血がショック 状態をま坧き，全身状態を悪化させ，脳循環障害をさら に悪化させること法，術後管理に括いてきわわて重要な 問題である.したがって，消化管出血の原因を正確に把 握して適切な処置をする必要がある。

脑障害に伴亏消化管出血 は， Rokitansky（1842）に上

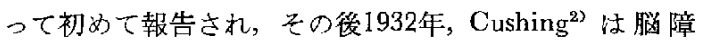
害に惹起さ和る胃十二指腸漬瘍について，臨床上の重要 性とその原因について報告し，視床下部の副交感神経刺 激に上って罢十二指腸潰愓をきたすと提唱し，神経性因 子の重要性を述べた. 以来 Cushing ulcer として有名で ある，その後腷障害と胃十二指晹病変との関係について

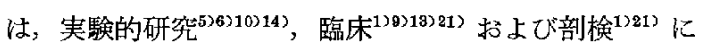
よる研究が多くなされ，消化管出血が出血性胃炎または 胃潰瘍に由来していることは明らかとなっている。

Table 1 Cases of gastroendoscopic examinations

\begin{tabular}{lrr}
\hline \multicolumn{1}{c}{ Diagnosis } & No. of cases & \multicolumn{1}{c}{$\%$} \\
\hline Putaminal hemorrhage & 27 & 57.5 \\
Subcortical hemorrhage & 3 & 6.4 \\
Thalamic hemorrhage & 1 & 2.1 \\
Caudate hemorrhage & 2 & 4.2 \\
Subarachnoid hemorrhage & 9 & 19.2 \\
Cerebral infarction & 2 & 4.3 \\
Cerebellar hemorrhage & 2 & 4.3 \\
Moyamoya disease & 1 & 2.1 \\
\hline Total & 47 & \\
\hline
\end{tabular}

しかしながら，脳血管障害に伴ら早期の胃十二指腸病 変を観察し，その病変と消化管出血との関倸について詳 細に言及した報告は少なく ${ }^{13)}$, 特に発症24時間以内の早 期病変についての報告はみない。

我々心発症後早期に胃内視鏡を行い，これを発症24時 間以内の超早期と，24時間加ら48時間，48時閒以後の3 つのグループに分けて検討し，早期胃十二指腸病変につ いて明らかにする。 ついで，この早期病変が消化管出血 とどのような関倸にあるか，また意識障害の程度，CT による障害部位と早期病変がどのよらな関係にあるのか 検討した，さらに消化管出血の予知，予防対策について 述べる。

\section{II 対象および方法}

\section{1. 対象}

1977年10月からら1979年 6 月までに，内視鏡が施行でき た脳血管障害47症例である。

被設部出血27例 $(57.5 \%)$ ともっとも多く，ついで腷 動脈癐 9 例 (19.2\%) である (Table 1)。平均年令注 59.3 才で男性28例，女性19例である。

\section{2. 胃内視鏡の施行時期および内視鏡所見の分類}

47 例中 2 例を除き全例手術施行例であり，手術直前を たは直後に全身麻醉下に内視鏡を行った，施行時期は発 症後 24 時間以内 25 例 $(53.2 \%) ， 24$ 時間加占 48 時問 施行 例は12例 $(25.2 \%) ， 48$ 時問以後に施行したのは10 例 (21.6\%) である.

\section{3. 内視鏡所見の分類}

1) 点状出血 (petechiae，P)：主として点状出血がみ られるむの。

2) 糜闌 (erosion，E)：点状出血のほかに白苔などの 他の変化が政られるもの.

Table 2 Gastroendoscopic findings within 24hrs from CVA

\begin{tabular}{ccccccccccccc}
\hline \multirow{2}{*}{$\begin{array}{c}\text { Level of } \\
\text { consciousness }\end{array}$} & \multirow{2}{*}{$\begin{array}{c}\text { No. of } \\
\text { cases }\end{array}$} & $\begin{array}{c}\mathrm{GI} \\
\text { blecding }\end{array}$ & & normal & $\mathrm{GP}(1)$ & $\mathrm{GP}(2)$ & $\mathrm{GP}(3)$ & $\mathrm{G}(\mathrm{U})$ & $\mathrm{G}(\mathrm{E})$ & $\mathrm{G}(\mathrm{H})$ & $\mathrm{DP}$ & $\mathrm{D}(\mathrm{U})$ \\
\hline $0 \sim$ & 9 & 1 & 6 & 2 & 1 & & & & & & \\
\hline $10 \sim$ & 30 & 6 & 3 & 2 & & 2 & & & & 1 & & \\
$100 \sim 300$ & 10 & 9 & 1 & 2 & 3 & 2 & 1 & & 1 & 1 & \\
\hline Total & 25 & 13 & 9 & 4 & 6 & 2 & 1 & 0 & 2 & 1 & 0 \\
\hline
\end{tabular}

GI: gastrointestinal, CVA: cerebrovascular accident, GP(1): gastric petechiae, grade 1, GP(2): gastric petechiae, grade 2, GP(3): gastric petechiae, grade 3, G(U) : gastric ulcer, G $(\mathbf{E})$ : gastric crosion, $\mathrm{G}(\mathbf{H})$ : gastric hyperemia, $\mathbf{D P}$ : duodenal petechiae, $\mathbf{D}(\mathbf{U})$ : duodenal ulcer 
Table 3 Gastroendoscopic findings between 24 and $48 \mathrm{hrs}$ after CVA

\begin{tabular}{|c|c|c|c|c|c|c|c|c|c|c|c|}
\hline \multirow{2}{*}{$\begin{array}{l}\text { Level of } \\
\text { consciousness }\end{array}$} & \multirow{2}{*}{$\begin{array}{l}\text { No. of } \\
\text { cases }\end{array}$} & \multirow{2}{*}{$\begin{array}{c}\text { GI } \\
\text { bleeding }\end{array}$} & \multicolumn{9}{|c|}{ Gastroendoscopic findings } \\
\hline & & & normal & $\mathrm{GP}(1)$ & $\mathbf{G P}(2)$ & $\mathrm{GP}(3)$ & $\mathrm{G}(\mathrm{U})$ & $\mathbf{G}(\mathbf{E})$ & $\mathrm{G}(\mathrm{H})$ & $\mathrm{DP}$ & $\mathrm{D}(\mathbf{U})$ \\
\hline $0 \sim$ & 7 & 2 & 3 & 2 & 1 & 1 & & & & & \\
\hline $10 \sim 30$ & 4 & 1 & 1 & 2 & & & & & & & \\
\hline $100 \sim 300$ & 1 & 1 & & & & 1 & & & & & \\
\hline Total & 12 & 4 & 4 & 4 & 1 & 2 & 0 & 0 & 0 & 0 & 0 \\
\hline
\end{tabular}

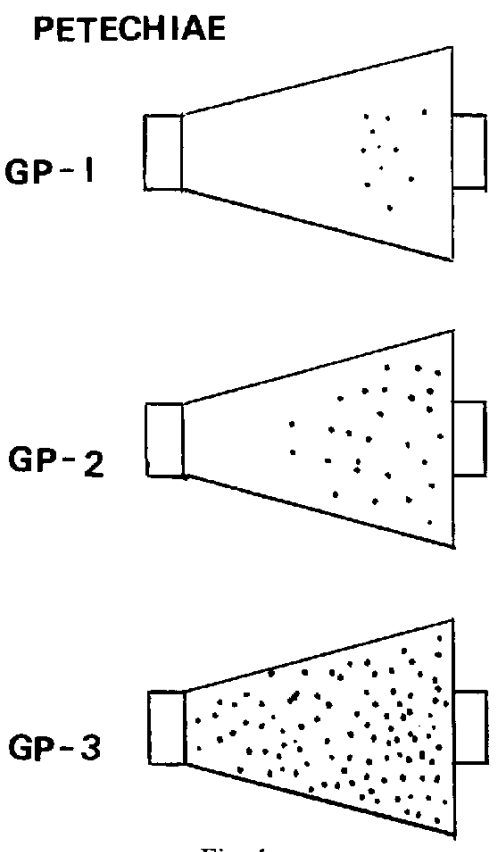

Fig. 1

3) 潰瘍 (ulcer, U) : 浅い潰瘍で凝血を認める.

4) 発赤 (hyperemia, H) : 粘膜の充血.

5) 正常 (normal)

上記の 5 つの所見に分汁，その病変が胃壁に孙られる 場合をGとし，十二指腸ではDとした，たとえば，胃に 点状出血のあるときにはGPとした．胃内視鏡施行時の 意識レベルの記載は3-3-9度方式によった的。

消化管出血: 下血, 吐血または胃留置カテーテルの褐 色、コーヒー様の出血をきたしたものとした。

CT scan：日立 CT-Hにより原則として OMline よ り $15^{\circ}$ の角度で撮影した。

\section{I 結 果}

\section{1. 内視鏡所見}

1）超早期の胃病変について

24時間以内に内視鏡が施行できた25症例についてま上

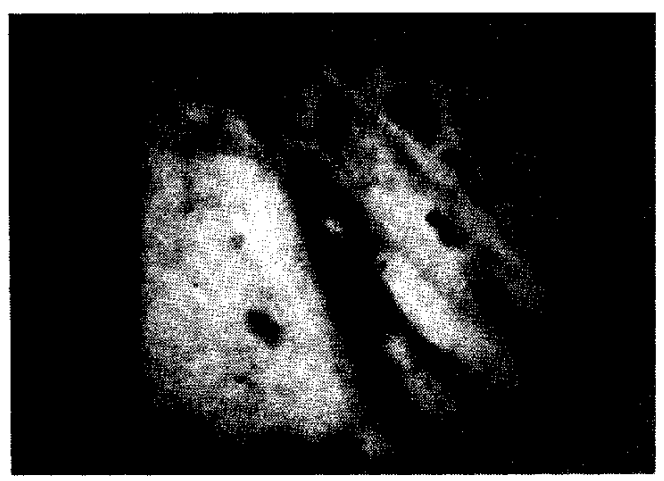

Fig. 2 Multiple petechiae with bleeding observed by gastroendoscopy. GP(3)

めたのが Table 2 である.25例中点状出血12例，潰演 1 例である，しかしこの潰瘍は陳旧性のものであり，異常 所見の主たるものは点状出血であった．をた４8時間充 での例をみてむ，12例中 7 例に点状出血索認めている (Table 3).これらの結果加ら，発症後24時間, 遅くと も48時間以内では，点状出血が特徽的早期胃病変といえ る (Fig. 2),

2) 点状出血 (petechiae) の分布と程度による分類 点状出血は，軽度の場合は胃体部に限局してみられ， ついで胃体部に散在性にみるら机る。さらに高度になると 胃壁全体に及び，点状出血唯広範囲にみられる。これら をFig. 1 のよらにそれれぞれ GP(1)，GP(2)，GP(3)と分 類した。

\section{2. 意識状態と内視鏡所見}

発症後 24 時閒以内の胃内視鏡所見をみると, 意識が0 $\sim 3$ の軽度意識障恝症例では，9例中 6 例が正常所見で あり，点状出血のみられる例では $\mathrm{GP}(1) 2$ 例, $\mathrm{GP}(2) 1$ 例 と軽度または中等度である。意識が中等度障害されてい る10 300状態では，6例中 2 例が正常で, $\mathrm{GP}(2) 2$ 例, 胃 の発赤が 1 例である，さらに半昏睡から昏睡 $(100 \sim 300)$ と重症になると，正常历見は10例中 1 例のみであり，点 状出血肪 7 例に観察され，ᄂ加もGP(1) 2 例，GP(2) 3 例，GP(3) 2 例と中等度ないし高度の点状出血がみかられ 
Table 4 Gastroendoscopic findings after $48 \mathrm{hrs}$ from CVA

\begin{tabular}{|c|c|c|c|c|c|c|c|c|c|c|c|c|}
\hline \multirow{2}{*}{$\begin{array}{l}\text { Level of } \\
\text { consciousness }\end{array}$} & \multirow{2}{*}{$\begin{array}{l}\text { No. of } \\
\text { cases }\end{array}$} & \multirow{2}{*}{$\begin{array}{c}\text { GI } \\
\text { bleeding }\end{array}$} & \multicolumn{9}{|c|}{ Gastroendoscopic findings } & \multirow[b]{2}{*}{$\mathbf{D}(\mathbf{E})$} \\
\hline & & & normal & GP(1) & $\mathrm{GP}(2)$ & $\mathrm{GP}(3)$ & $\mathrm{G}(\mathrm{U})$ & $G(E)$ & $\mathrm{G}(\mathrm{H})$ & $\mathrm{DP}$ & $\mathbf{D}(\mathrm{U})$ & \\
\hline $0 \sim$ & 7 & 1 & 3 & 2 & & & & 1 & & & & \\
\hline $10 \sim 30$ & 2 & 1 & 1 & & & & & 1 & & & 1 & \\
\hline $100 \sim 300$ & 1 & 1 & & & 1 & & & & & & 1 & 1 \\
\hline Total & 10 & 3 & 4 & 2 & 1 & 0 & 0 & 2 & 0 & 0 & 2 & 1 \\
\hline
\end{tabular}

Table 5 GI blecding and gastroendoscopic findings

\begin{tabular}{llc}
\hline Findings & $\begin{array}{c}\text { GI bleeding } \\
21 \text { cases }\end{array}$ & $\begin{array}{c}\text { Non-GI bleeding } \\
26 \text { cases }\end{array}$ \\
\hline normal & 1 & 16 \\
GP $(1)$ & $2(25 \%)$ & 6 \\
GP $(2)$ & $8(89 \%)$ & 1 \\
GP $(3)$ & $4(100 \%)$ & 0 \\
G(U) & 1 & 0 \\
G(E) & 2 & 0 \\
G(H) & 1 & 2 \\
DP & 1 & 0 \\
D(U) & 2 & 0 \\
D(E) & 1 & 0 \\
D(H) & 0 & 1 \\
\hline
\end{tabular}

た（Table 2).すなわち発症24時問以内の急性期胃十二 指腸病変注，意識状態が悪化するにしたがい，点状出血 が限局性のものから西漫性の高度なものとなり，いわゆ る出血性胃炎の像を呈する.48時間以内でも同倳の所見 でかる.ところが48時閒以後の离見は，点状出血上りも むし乃潰瘍とか, 糜燘性病変がみられ, 点状出血沈むし ろ減少する傾向にある，しかし，意識状態との関係にっ いては症例す少なく，今回は明らかにできなかった (Table 4).

\section{3. 消化管出血亡胃内視鏡所見}

消化管出血をきたした症例と，消化管出血のみられな かった症例の内視鏡所見を比較したのが Table 5 であ る. 消化管出血の如られたのは21症例であり，異常所見 のなかった例は1例のみで京。，異常所見としては点状 出血怔もっと多く，GP(1) 2 例， $\mathrm{GP}(2) 8$ 例, GP(3) 4 例 で, 点状出血の中等度加ら高度の例が21例中12例と過半 数にみられた。十二指腸㵝瘍 2 例と胃潰瘍吕 1 例に認め られた．たたし胃潰痛の1例樯旧性であった.

消化管出血のなかった26症例のらち, 正常所見であっ たものは16例で，異常所見は GP(1)6例，GP(2)1例のみ

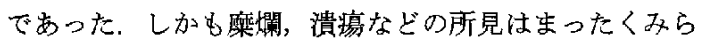

Table 6 GI bleeding and level of consciousness

\begin{tabular}{rrrrr}
\hline \multicolumn{1}{c}{$\begin{array}{c}\text { Level of } \\
\text { consciousness }\end{array}$} & $\begin{array}{l}\text { No. of } \\
\text { cases }\end{array}$ & GI bleeding & $\begin{array}{c}\text { Non-GI } \\
\text { bleeding }\end{array}$ \\
\hline $0 \sim 3$ & 21 & $5(23.8 \%)$ & $16(76.2 \%)$ \\
$10 \sim 30$ & 13 & $4(30.8 \%)$ & $9(69.2 \%)$ \\
$100 \sim 300$ & 13 & $12(92.3 \%)$ & $1(7.7 \%)$ \\
\hline Total & 47 & 21 & 26 \\
\hline
\end{tabular}

れなかっった，胃内視鏡の点状出血の程度から，消化管出 血の有無を調心゙てみると, GP(1)の場合, 消化管出血をき たしたもの法わずか8例中 2 例 $(25 \%)$ である、GP(2) では 9 例中 8 例 $(89 \%)$ に出血がみられ，GP(3)では 4

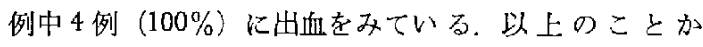
ら，胃内視鏡で GP(2)，GP(3)のある例に出血をきたしや すく，正常むしくは GP(1)の症例では消化管出血をきた すことはきわめてま机である。すなわち早期の出血源は 点状出血に由来している。一方出血の原因としての潰瘍 は，自験例では 2 例であり，いずれも発症後48時間以降 であり，潰癔が原因となる消化管出血怯，早期には少な いと考えられる。

\section{4. 消化管出血亡意識状態}

消化管出血と胃内視鏡施行時の意識状熊との関係を Table 6 に示した. 意識状態が $0 \sim 3$ の軽度意識障害例 で汢消化管出血注21例中 5 例 $(23.8 \%)$ であり，10ஃ30 の中等度意識障害例では13 例中 4 例 $(30.8 \%$ ) 飞方 れ，100 300の高度意識障害例では，実に13 例 中 12 例 (92.3\%) と高率に消化管出血をきたしている。すなわ ち，意識障害が高度になるほど消化管出血が高頻度に聕 起さ札る。このこ上はまた, 上行性網様体賦活系, 視床 下部など意識の中枢への障害の程度と関連が媣いことを 示している。

\section{5. 早期胃内視鏡所見と CT 像について}

内視鏡で胃点状出血のみられない症例の，CTでみら れる出血部位をトレースして重ねたものがFig. 3Aであ る。出血が視床执よび視床下部に及ぶものはなく，檤室 穿破もみられない，ところが $\mathrm{GP}(3)$ の例では視床出血， 


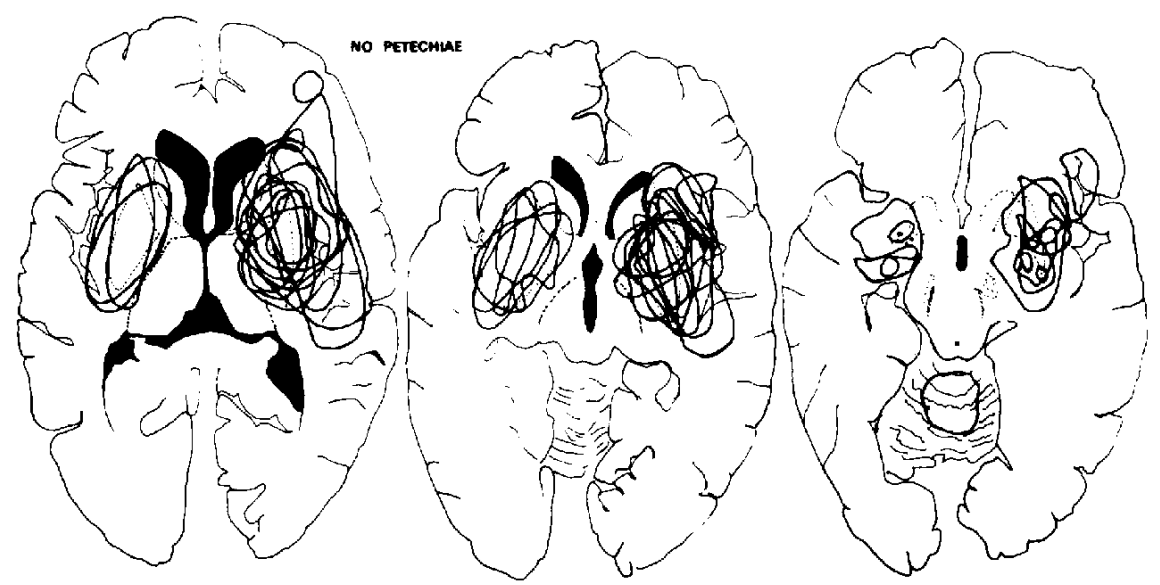

Fig. 3 A: Traces of axial CT sections, indicating intracerebral hemorrhage. 17 cases of normal gastroscopic findings. Hemorrhages are located in putaminal or small subcortical regions.

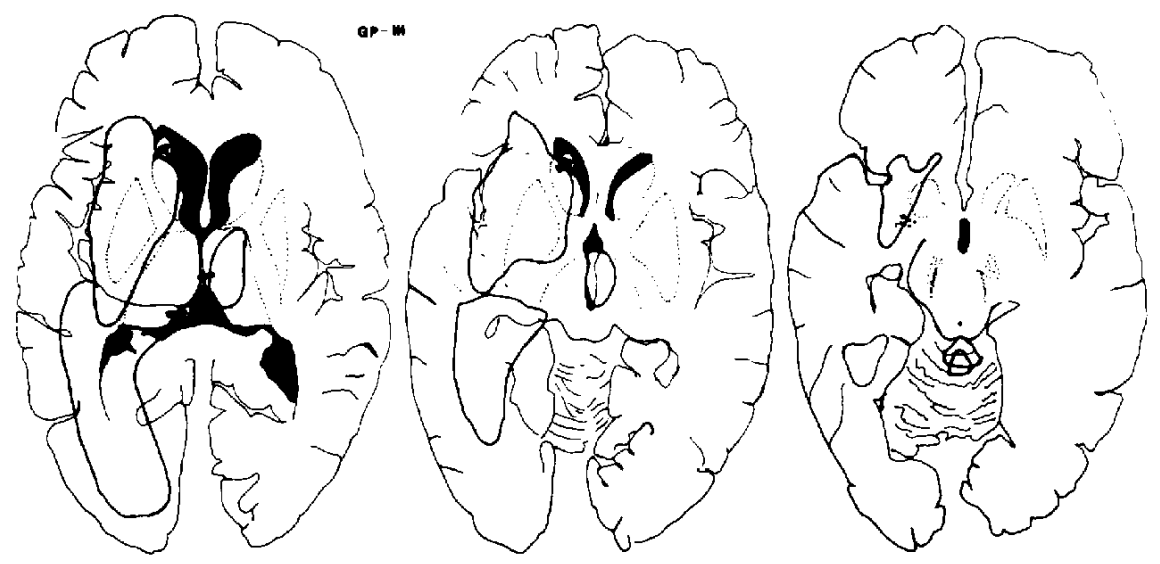

Fig. 3 B: Cases of GP (3). Rt. putaminal, Lt. large subcortical and Lt. massive putaminal hemorrhage which ruptured into the third or lateral ventricles.

大出血に伴う脳室穿破などで，視床下部，脳幹部への影 響が強いと考えられる症例である(Fig. 3B)，GP(1)，GP (2)の例についても同様に検討してみると，GP(2)に䋆 て $\mathrm{GP}(1) よ り ，$ 視床，視床下部により障害が及んでいる と芳えられた，視床，視床下部，媨幹部に障害が及んで いるものほど胃点状出血が高度であることが推察され た.

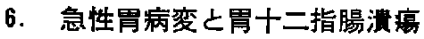

胃十二指腸潰瘍が発見された 2 例に胃切除を行った. 1 例日は59才男性, 右被款部出血例である。発症後18日 目に消化管出血をきたし，輸血によっても貧血が増悪し をため胃切除を行った，2 例目注49才男性の前交通動脈 破裂症例である，発症11日目に大量消化管出血のため胃 切除を行った，いずれも経過良好であった。禹症例とも に消化管出血が18日日，11日目と遅れて発症しているの
が点状出血に起因する出血上相違する。漬場形成は点状 出血に代表される早期病変より遅れて発症すると考えら れるが，この両者の関倸についてはいまだに明らかでな い.

\section{IV 考 案}

\section{1. 超早期胃病変について}

24時間以内に施行できた25症例䘮検討した結果，早期 の胃病変の特徴は, 点状出血であるといら結論に至った. その点状出血の程度によって，次の 3 つの型に分類する ことができる．すなわち，点状出血が胃体部に限局性に 少数認められる軽度のもの $\mathrm{GP}(1)$ ，胃体部を中心に散在 性にみられるもの $\mathrm{GP}(2)$ ，胃壁全体に及ぶもの $\mathrm{GP}(3)$ に 大別した (Fig. 1)。従来脑卒中にみ放れる胃十二指腸病 変としては多彩な糜爛，潰瘍などが報告されている ${ }^{132}$. 
しかしこれらの病変は，早期点状出血に引き続いて起こ る二次的変化であると考える.

\section{2. 早期の胃病変発生機序}

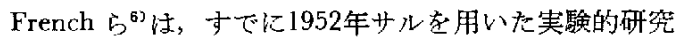
から，出血性糜爛が視床前部の破壊で交感神経が興奤す ると発生し，潰場は副交感神経系の與蓄によると報告し た. 城戸 ${ }^{10}$ は視床下部に雷気刺激を与えると胃十二指腸 に出血，應爛を惹起させることができ，さらにレせルピ ン前投与後視床下部に電気刺激を与光ると, 重䉆な潰湟 を発生せしめることを証明している，Feldman ら゙は， 副交感神経と交感神経の中枢性自律神経のバランスがく ずれをときに，胃に糜爛をつくると述べている。また水 島ら ${ }^{14)}$ は，ストレス潰瘍のメカニズムとしてラットを用 い，拘束水浸によるストレス実験で胃粘膜病変を観察し ているが，視床下部心直接の影響と同様に，大脑皮質か ら視床下部が刺激されて胃十二指腸病変が惹起されるこ とを指摘している。

\section{3. 消化管出血の原因}

消化管出血の原因としてもっとも多いのは点状出血か らである。これらは，一般的にはショックを惹起するは どの大量出血は比較的少ない，大出血の原因となるのは むしろ潰瘍加らであると考えら机え，消化管出血の機序

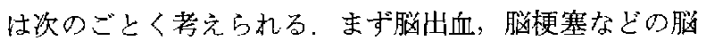
障害により，視床下部が直接または問接的に損傷される 上，交感神経采の異常與㖣に上り splanic nervet介して 胃細小動脈の収縮，そ札に伴ら5っ血，同時に動静眽吻 合の開放に上り胃粘膜が虚血状態となり，その結果，内視 鏡でみられる胃壁の点状出血が形成される。この出血が 高度になると，急性期の消化管出血の主原因となる。さ らに交感神経系だけでく, 副交感神経系の興奮に上り 迷走神経を介して骨運動の元谁, 過緊張の状態上なり, 胃粘膜の虚血を斯長する。 そして gastric mucosal barrier

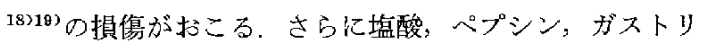
ンなどの分泌の元進, 化学イオンの back diffusion ${ }^{4}$ の作 用などが，脆弱化した胃粘膜に攻撃因子として作用し， 胃の糜爛，さらに注十二指腸潰瘍を形成せしめ，消化 管出血惹起すると孝えている，視床下部下垂体系の作 用であるが，視床下部刺激により下垂体から ACTH が 分泌され，ついで副腎皮質から corticosteroid の分泌が なされ，この作用により塩酸, ペプシンが増加し，粘液 の分必を抑制するといわれている。しかしこの働きはむ しろ副次的であると思われる。尾田 ${ }^{17)} は$, 臨床研究から 中枢性障害に上る潰瘍で法，視床下部下垂体系の㗢きは 副欢的意味しかないと結論しており，glucocorticoidの大 量投与がむしろ潰瘍形成の予防的効果があると述べてい
る.

\section{4. 消化管出血に対する予防および治撚}

消化管出血の原因性，すで汇述べたように大きく2つ に分けられる，1 万法早期にみられる点状出血による出 血性胃炎であり，1 つは遅発性の胃十二指腸潰煌であ る. 前者は GP(1)施 $\mathrm{GP}(3)$ に分類できるが, GP(1)のご とく胃体部限局性の点状出血の場合には，特に治療の必 要性はない，GP(2)と GP(3)では消化管出血の危険性は高 く，消化管出血を予想して加療する必要がある，視床下 部への浮腫，压迫による影響を軽減するためにステロイ ド投与孛行ってみるぶきである，尾田はステロイド使用 例が，非使用例より有意に消化管出血の発生が少ない上 報侣している ${ }^{17)}$. 視床下部自律神経調節の目的で sulpiride, ヒスタミン $\mathbf{H}_{2}$ 受容体拮抗哓, cimetidine ${ }^{7}$, 抗 ガストリン作用による secretin，胃酸中和のため antacid therapy3)などが試みられているが，確実な治療はない。

腷出血やクモ膜下出血に惹起する消化管出血に対して は，視床下部一の影響を軽減するためにも早期手術を施 行した方が良いと考えている。 ついで潰瘍を形成したも のについてはまず保存的治療を試孤，これに抵抗する例 に洨胃切除、レーザーによる止血，gastroscopic electrosurgery などが行われる。我々は2 例に胃切除を施行し 救佮した. Goodman は, 術後の出血の重要な要素とし て低血圧と sepsisをあげているが，このことは全身管理

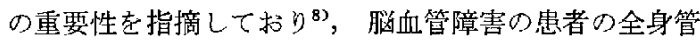
理がゆきとどいていれば，消化管出血を柽減することが できるのではないかと思われる。

我々は中枢性消化管出血の対策としては, 意識障害の ある症例には術中に胃内視鏡を行い，その所見に応じて 対処するのがもっとも良い方法であると考えている。

\section{$\mathrm{V}$ 結 論}

1. 腮血管障害にみられる発症24時間以内の早期胃十 二指腸病変は点状出血であり，麻闌や潰瘍江二次的遅発 性病変である。

2. 点状出血は $\mathrm{GP}(1)$ （胃体部限局性〉，GP(2)（中等 度胃体部散在性)，GP(3)（胃壁全体散在性）に大別でき る。消化管出血の頻度は $\mathrm{GP}(\mathbf{1})$ で $25 \% ， \mathrm{GP}(2)$ で $89 \%$ ，GP (3)で $100 \%$ である.

3. 点状出血は意識障害の重篤なるのほど広範にな る. CT 上血腫が視床下部に影響を及ぼすと考えられる 例汇, 点状出血汢広範になり消化管出血を惹起する。

4. 脳血管障害に伴ら消化管出血の対策は, 早期に胃 内視鏡を行いその所見に応して対処すべきである。

5. 胃十二指腸潰瘍と点状出血の関係は明らができ 
なかったが，点状出血が軽度であってす，遅発性の消化 管出血の場合には，潰場形成の可能性を考え胃内視鏡を

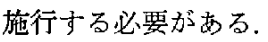

本要旨については，第38回日本媨神経外科学会総会に 招いて発表した。

\section{文献}

1) 荒木千里 : 脳出血に括ける胃・十二指腸潰煌. 日臨28：2480-2485，1970

2) Cushing, H.: Peptic ulcers and interbrain. Surg Gynecal Obstet 55: 1-34, 1932

3) Curtis, L. E., Simonian, S., Buerk, C. A., Hirsch, E. F. \& Sorofr, H. S.: Evaluation of the effectiveness of controlled $\mathrm{pH}$ in management of massive upper gastrointestinal bleeding. Am J Surg 125: 474-476, 1973

4) Davenport, H. W.: Is the apparent hyposecretion of acid by patients with gastric ulcer consequence of broken barrier to diffusion of hydrogen ions into the gastric mucosa. Gut 6: 513-514, 1965

5) Feldman, S. \& Birnbaum, D.: Gastric lesions following hypothalamic stimulation. Arch Neurol 4: 308-317, 1961

6) French, J. D., Porter, R. W., von Amerogen, F. K. \& RANEY, R. B.: Gastrointestinal hemorrhage and ulceration associated with intracranial lesions. Surgery 32: 395-407, 1952

7) Freston, J. W.: Cimetidine in the treatment of gastric ulcer. Gastroenterology 74 No.2 (Part 2): $426-430,1978$

8) Goodman, A. A. \& Frey, C. F.: Massive upper gastrointestinal hemorrhage following surgical operations. Ann Surg 169: 180-184, 1968

9) 古瀬清次, 蛕名一夫, 石島 裕, 山崎 駿, 平 山昭彦，垰本勝司，内田泰史，唐沢 淖，料池
晴彦：開頭術後の大量消化管出血々対する 外科 的適店，手術26:1151-1155，1972

10)城戸良之的：視床下部と胃の機能. 脑神経 19: $467-476,1967$

11) Jama, R. H., Periman, M. H. \& Matsumoto, T.: Incidence of stress ulcer formation associated with steroid therapy in various shock states. Am J Surg 130: 328-331, 1975

12) KARCH, S. B.: Upper gastrointestinal bleeding as a complication of intracranial disease. $J$ Neurosurg 37: 27-29, 1972

13)北村竜男：急性期䏼卒中に合併する胃病変. 臨 床神経 $15: 541-549,1975$

14) 水島和雄, 岡村毅与志, 原田一道, 林 英樹, 並木正義：実験的急性胃病変. 胃と腸 $13: 223-$ 232,1978

15）沖中重雄，松尾 裕，関 敦子，椿 忠雄, 関 増爾, 龟山正邦 : 脳卒中と胃腸出血. 老年病4： $837-844,1960$

16）大田富雄：急性期意識障害の新しいGrading とその表現法. 第 3 回脑卒中外科研究会講演集, 1975, pp 61-66

17) 尾田宣仁：中枢性消化管出血併発例に対する Glucocorticoid 投与可否に関する検討. 脳外 7： $653-657,1979$

18) Silen, W. \& Skillman, J. J.: Stress ulcer, acute erosive gastritis and the gastric mucosal barrier. Int Med 19: 195-212, 1974

19) Skillman, J. J. \& Silen, W.: Acute gastroduodenal "STRESS" ulceration: barrier disruption of varied pathogenesis? Gastroenterology 59, No. 3: 478-482, 1970

20)竹森信男, 牧野宏太郎, 後藤 聡, 伊藤殚史, 高村春雄：重症譄障害に伴う急性胃腸管 出 血. 日外会誌74:521-533，1973

21）山口一彦 : 高血圧性脳出血に合併寸る胃十二 指腸病変に関する臨床病理学的研究. 脳神経 25 : $1567-1581,1973$ 